\title{
Pengaruh Latihan Bench Dip Terhadap Kemampuan Passing Bola Basket Pada SMAN 1 Narmada Tahun 2020
}

\author{
Andi Irawan, Dadang Warta Chandra Wira Kusuma, Nurtajudin \\ Program Studi Pendidikan Olahraga dan Kesehatan, FIKKM Universitas Pendidikan Mandalika \\ irawan-andi@gmail.com
}

Received: Januari 2021; Accepted: Februari 2021; Published: Maret 2021

Ed: Maret 2021; 8(1): 57-66

\begin{abstract}
Abstrak
Permasalahan penelitian ini adalah rendahnya hasil shooting yang dimiliki oleh siswa disebabkan karena kemampuan passing maupun shooting masih kurang maksimal. Hal ini terlihat ketika siswa saat melempar dan menagkap, melakukan passing bola sering tidak sampai ke teman yang diberikan, passing dalam merupakan kunci permainan bola basket. Tujuan Penelitian ini merupakan penelitian untuk menguji signifikansi sampel yang berbeda dengan rumusan masalah yang diajukan adalah untuk mengetahui apakah ada Pengaruh latihan bench dip terhadap kemampuan passing bola basket pada SMAN 1 Narmada Tahun 2020". Metode penelitian untuk pengambilan subyek dalam penelitian ini adalah cluster random sampling yaitu teknik sampling yang memilih area atau kelompok sebagai sampelnya. Adapun sampel yang digunakan adalah siswa putra yang mengikuti ekstrakurikuler basket dengan jumlah 20 orang. Untuk memperoleh data dalam penelitian ini, maka digunakan metode tes perbuatan dan metode dokumentasi. Metode analisis data yang digunakan adalah uji-t (t-test). Hasil penelitian berdasarkan hasil uji t (t-test) menunjukkan nilai hitung t-test sebesar 26,29 maka besarnya taraf signifikan 5\% dan $\mathrm{N}$ sebesar 20, ternyata besarnya angka penolakan hipotesis nol yang di nyatakan dalam tabel adalah 2,069. Kenyataan ini menunjukkan bahwa nilai t hitung dari hasil analisis data sebesar 26,29 berada di atas angka penolakan hipotesis nol yang besarnya 2,069. ( Nilai $t=26,29>r$ tabel 2,069) maka dapat di simpulkan bahwa " Ada pengaruh latihan bench dip terhadap kemampuan passing bola basket pada SMAN 1 Narmada Tahun 2020.
\end{abstract}

Kata Kunci: latihan bench dip, passing, bola basket.

\begin{abstract}
The problem with this research is that the students' low shooting results are caused by their passing and shooting abilities that are still not optimal. This can be seen when students throw and catch, passing the ball often does not reach the given friend, deep passing is the key to the basketball game. The purpose of this study is to examine the significance of different samples with the formulation of the problem posed is to find out whether there is an effect of bench dip training on basketball passing abilities at SMAN 1 Narmada in 2020". The research method for taking subjects in this study is cluster random sampling, which is a sampling technique that selects an area or group as the sample. The samples used were male students who took part in basketball extracurricular with a total of 20 people. To obtain data in this study, the test method and the method of documentation were used. The data analysis method used is the t-test (t-test). The results of the study based on the results of the t-test (t-test) showed the calculated value of the t-test was 26.29, so the significance level was 5\% and $N$ was 20, it turned out that the number of rejection of the null hypothesis stated in the table was 2.069. This fact indicates that the value of $t$ arithmetic from the results of data analysis of 26.29 is above the number of rejection of the null hypothesis which is 2.069. ( $T$ value $=26.29>r$ table 2.069) it can be concluded that "There is an effect of bench dip training on basketball passing skills at SMAN 1 Narmada in 2020.
\end{abstract}

Keywords: bench dip exercise, passing, basketball. 


\section{PENDAHULUAN}

Pemberitahuan hasil Olahraga adalah salah satu aktifitas fisik maupun psikis seseorang yang berguna menjaga dan meningkatkan kualitas kesehatan seseorang tersebut.Olahraga banyak dilakukan oleh masyarakat, tidak hanya untuk menjaga kesehatan, tetapi sebagai sarana pendidikan bahkan sebagai sarana untuk mencapai prestasi. Menurut Giriwijoyo (2007:85) olahraga merupakan serangkaian gerak raga yang teratur dan terencana untuk memelihara gerak dan meningkatkan kemampuan gerak. Dengan perkembangan dan kemajuan teknologi memberikan pengaruh terhadap bidang keolahragaan sehingga mengalami kemajuan yang sangat pesat. Pengaruh Kamus Besar Bahasa Indonesia (2005:849), pengaruh merupakan daya yang ada atau timbul dari sesuatu (orang atau benda) yang ikut membentuk watak, kepercayaan atau perbuatan seseorang. Untuk itu perlu dilakukan beberapa upaya pembinaan dan pengembangan dibidang olahraga, yang bertujuan untuk mencapai prestasi yang optimal pada suatu kejuaraan baik di tingkat regional maupun Nasional. Salah satu contohnya adalah olahraga bola basket. Permainan bola basket adalah olahraga bola berkelompok yang terdiri atas dua tim yeng beranggotakan masing-masing lima orang yang bertanding dan mencetak point dengan memasukan bola kedalam ring atau keranjang lawan.

Latihan pada prinsipnya adalah memberikan tekanan atau stres fisik secara teratur, sistematis, berkesinambungan, sedemikian rupa sehingga dapat meningkatkan kemampuan fisik di dalam melakukan kerja (Fox, 1988: 7) dalam buku Syahfrizar (2007). Latihan adalah aktivitas manusia yang menunjang terhadap pemenuhan kebutuhan fisiknya(Widodo, 2014).Sedangkanmenurut Harisenjaya (1996: 114), kegiatan latihan atau training merupakan salah satu usaha seseorang untuk menyesuaikan keadaan jasmaninya terhadap pekerjaan atau kegiatan yang diperberat atau lebih berat lagi dengan cara setahap demi setahap, tubuh kita dibiasakan menerima atau melakukan pekerjaan yang lebih berat secara berangsur-angsur dan meningkat menuju kemampuan yang lebih tinggi sampai menerima prestasi yang maksimal. Dalam permainan bola basket terdapat 3 posisi utama,yaitu : forward,pemain yang tugas utamanya adalah mencetak poin dengan memasukan bola ke keranjang lawan, defense,tugas utamanya adalah menjaga pemain lawan agar kesulitan memasukan bola ke keranjang, playmaker,pengatur alur bola dan strategi yang dimainkan oleh rekan-rekan setimnya.Selain itu basket merupakan salah satu olahraga paling populer di dunia, hal ini dapat dilihat dari penggemarnya yang berasal dari segala usia, khususnya kaum remaja merasakan bahwa bola basket adalah olahraga yang menyenangkan, kompetitif, mendidik, menghibur dan menyehatkan.

Dalam permainan bola basket dimana hampir diperlukan semua kemampuan tubuh manusia baik fisik, mental dan intelektual merupakan komponen-komponen yang berkaitan dan tidak dapat terpisahkan. Untuk mencapai prestasi yang maksimal sudah barang tentu mempunyai berbagai teknik dasar yang harus dikuasai.Setiap pemain harus memiliki teknik dasar yang baik. Beberapa teknik dasar dalam permainan bola basket menurut para ahli olahraga seperti Wissel (2009: 9), ada beberapa macam teknik dasar yaitu: (1) gerakan kaki (foot work), (2) bertahan, (3) menggiring bola (dribbling), (4) melempar dan menangkap bola (passing), (5) menembak bola ke dalam keranjang (shooting), (6) bergerak dengan bola, (7) bergerak tanpa bola. Kemenangan dalam permainan bola basket selain ditentukan oleh skor akhir yakni menembakkan bola ke ring (shooting)kemampuan teknik dasar passing bola basket juga sangat penting karena pemain harus mengoper bola basket dengan tepat sasaran kepada pemain lain. Passing merupakan gerakan yang sering dilakukan untuk mengecoh dan mengamankan bola dari lawan.Mengoper bola setinggi dada (chest pass), menurut Ahmadi (2007: 13), mengoper bola dengan dua tangan dari depan dada merupakan gerakan yang sering dilakukan dalam suatu pertandingan bola basket. 
Permainan bola basket di SMAN 1 Narmada saat ini cukup berkembang dilihat dari banyaknya siswa yang mengikuti ekstrakurikuler bola basket dan berbagai kejuaraan yang telah diikuti. Permasalahan penelitian Rendah nya hasil shooting yang dimiliki oleh siswa disebabkan karena kemampuan passing maupun shooting masih kurang maksimal. Hal ini terlihat ketika siswa: (1) saat melempar dan menagkap bola basket tingkat kemampuan passing nya masih kurang maksimal, (2) saat melakukan passing bola sering tidak sampai ke teman yang diberikan karena kemampuan otot masih kurang. Kemampuan passing dalam permainan bola basket perlu dilatih karena passing merupakan kunci untuk mengatur irama permainan dan penguasaan bola. Untuk meningkatkan hasil passing bola basket, penulis ingin melakukan latihan untuk meningkatkan kekuatan otot lengan,terutama otot lengan bagian belakang atau otot trisep. Latihan bench dip untuk meningkatkan otot trisep penulis ingin menggunakan jenis latihan bench dip,yang dimana media yang digunakan adalah bangku sebagai media tumpuan lengan. Latihan bench dip adalah sejenis latihan yang bertujuan untuk meningkatkan kekuatan otot lengan atas bagian belakang (trisep) dan merupakan latihan yang bersifat mengisolasi otot trisep secara penuh.

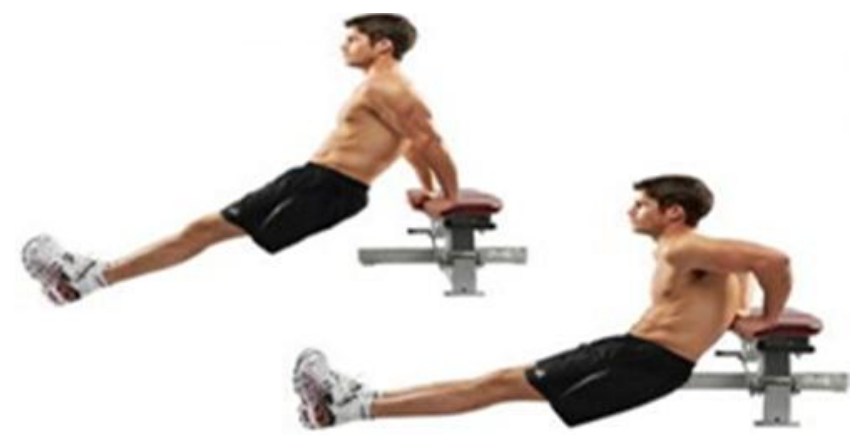

Gambar 1 Latihan Bench dip. (https://www.google.com/search?q=latihan+bench+dip\&safe)

Tujuan adalah untuk mengetahui ada Pengaruh latihan bench dip terhadap kemampuan passing bola basket pada SMAN 1 Narmada Tahun 2020. Permainan bola basket merupakan salah satu olahraga paling populer di dunia, hal ini dapat dilihat dari penggemarnya yang berasal dari segala usia, khususnya kaum remaja merasakan bahwa bola basket adalah olahraga yang menyenangkan, kompetitif, mendidik, menghibur dan menyehatkan. Dalam permainan bola basket dimana hampir diperlukan semua kemampuan tubuh manusia baik fisik, mental dan intelektual merupakan komponen-komponen yang berkaitan dan tidak dapat terpisahkan. Untuk mencapai prestasi yang maksimal sudah barang tentu mempunyai berbagai teknik dasar yang harus dikuasai dengan baik oleh para pemain basket yang ingin berprestasi baik seperti drible, passing, rebound, pivot dan shooting. Kemenangan dalam permainan bola basket selain ditentukan oleh skor akhir yakni menembakkan bola ke ring (shooting), passing bola basket juga sangat penting karena pemain harus mengoper bola basket dengan tepat sasaran pada pemain yang akan melakukan shooting begitu juga sebaliknya pada pemain yang akan melakukan shooting harus mampu menerima passing bola dengan baik dan tepat. 


\section{METODE}

Dalam penelitian ini rancangan penelitian yang digunakan adalah dengan jenis penelitian menggunakan Eksperimen ini masih terdapat variabel luar yang berpengaruh terhadap terbentuknya variabel terikat. Sumber Data yang di gunakan adalah data kuantitatif yang berupa hasil pretest dan post tes hasil passing bola basket penelitian. pengumpulan data hasil eksperimen yang merupakan variabel dependen (terikat) itu bukan semata-mata dipengaruhi oleh variabel independen (bebas). Rancangan Penelitian dengan desain "One group pretest-postest design metode, Dalam desain ini tidak ada kelompok kontrol dan subjek tidak ditempatkan secara acak. Kelebihan desain ini adalah dilakukan pre-test dan pos-test sehingga dapat diketahui dengan pasti perbedaan hasil akibat teratment atau perlakuan yang diberikan. (Sumber: Suryabrata, 2014:102).

\begin{tabular}{|c|c|c|}
\hline Pre-test & Treatment & Post-test \\
\hline $\mathrm{T}_{1}$ & $\mathrm{X}$ & $\mathrm{T}_{2}$ \\
\hline
\end{tabular}

Gambar 2. Desain Penelitian One group pretest-postest design

(Sumber: Suryabrata, 2014, hlm. 102)

Keterangan:

$\mathrm{T} 1$ = Pre-test (tes awal) melempar dan menangkap bola basket (passing)

$\mathrm{X}=$ Treatment/perlakuan

$\mathrm{T} 2$ = Post-tes (tes akhir) melempar dan menangkap bola basket (passing).

Prosedur Untuk memperoleh data yang valid dan akurat yang diperlukan oleh penulis maka dibutuhkan instrumen. Instrumen adalah alat ukur yang digunakan untuk mengumpulkan data dalam penelitian. Sedangkan menurut Suharsimi Arikunto (2010:203 ) Instrumen penelitian adalah alat atau fasilitas yang digunakan oleh peneliti dalam pengumpulan data penelitiannya. Jadi Instrumen itu harus disusun sedemikian rupa agar dapat secara tepat merekam data yang dimaksud. Dalam penelitian ini instrument penelitannya adalah tes perbuatan sebagai berikut, Tes kemampuan passing bola basket (Hulfian, 2014).

1) Sampel dengan memegang bola di tengah berdiri dibelakanggaris yang jauhnya $3 \mathrm{~m}$ dari tembok.

2) Setelah aba-aba "ya", sampel berusaha melemparkan bola dengan lemparan datar dari depan dada (chest pass) sebanyak mungkin ke tembok dalam waktu 30 detik.

3) Selama melakukan tes, sampel tidak boleh menginjak atau melewati garis.

4) Apabila pada waktu melakukan lemparan, salah satu atau kedua kaki sampel menginjak atau melewati garis, maka lemparan tersebut dianggap tidak sah dan tidak diberi angka.

5) Lemparan dihitung sejak bola lepas dari kedua tangan.

6) Jumlah lemparan yang sah selama 30 detik dihitung sebagai nilai tes passing 


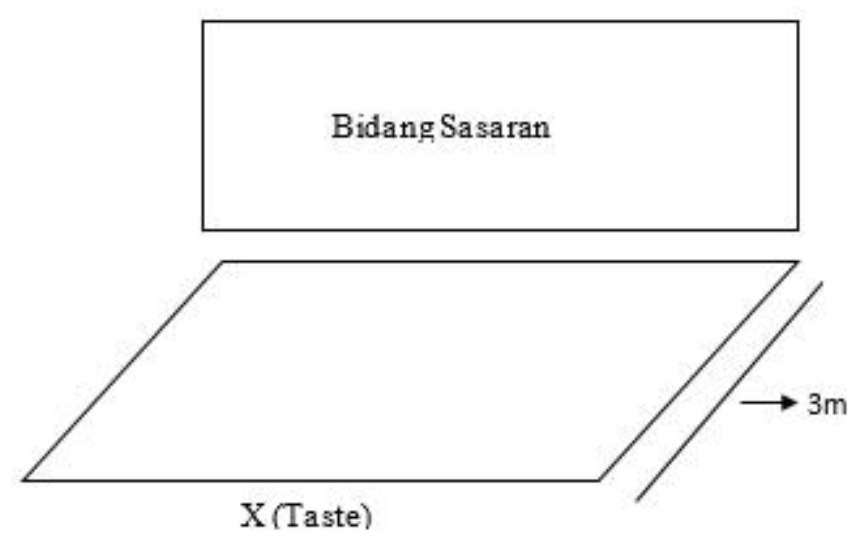

Gambar 3. Diagram lapangan tes ketepatan melempar dan menangkap bola basket.

Populasi adalah wilayah generalisasi yang terdiri atas: obyek/subyek yang mempunyai kualitas dan karakteristik tertentu yang ditetapkan oleh peneliti untuk dipelajari dan ditarik kesimpulannya (Sugiyono, 2013: 80). Sampel adalah bagian dari jumlah dan karakteristik yang dimiliki oleh populasi tersebut (Sugiyono, 2012: 118). Menurut Suharsimi Arikunto sampel adalah sebagian atau wakil dari populasi yang diteliti.. Sehubungan dengan hal tersebut di atas, dalam penelitian teknik dalam pengambilan subyek penelitian menggunakan Cluster Random Sampeling. Cluster random sampling merupakan teknik sampling yang memilih area atau kelompok sebagai sampelnya,bukan individu

(Hulfian, 2014 :25). Hal ini dilakukan karena objek terlalu luas, Dimana teknik pengambilan sample acak kluster dilakukan dengan mengambil beberapa kluster atau kelompok dan setelah kelompok itu terambil, semua atau sebagian unit dalam masing-masing kelompok diambil secara acak sebagai sample. Adapun sampel yang digunakan adalah perwakilan dari siswa putra yang mengikuti ekstrakurikuler dengan jumlah 20 orang.

Teknik pengumpulan data Seorang peneliti harus tepat memilih dan mencari dimana sumber data berada. Oleh karena seorang peneliti harus mampu menentukan dengan cepat dan tepat dimana sumber data dapat diperoleh (Sukandarrumidi, 2004: 69). Dokmentasi, observasi, dan tes perbutan Pengumpulan data dilakukan dengan metode dokumentasi dan tes perbuatan. Metode dokumentasi adalah suatu cara mengumpulkan data-data berupa dokumentasi siswa Putra SMAN 1 Narmada tahun 2020. Sedangkan metode tes perbuatan digunakan untuk memperoleh data-data tentang peningkatan passing sepak bola, metode observasi dalam penelitian ini dimaksudkan untuk melihat apakah proses pengumpulan data dilakukan benar atau tidak

Analisa Data Untuk menguji hipotesis penelitian yang diajukan, maka digunakan teknik analisis inferensial yaitu uji t (t-test) untuk sampel independent (terikat) dengan rumus sebagai berikut:

$$
t=\frac{\sum D}{\sqrt{\frac{N \cdot \sum D^{2}-\left(\sum D\right)^{2}}{(N-1)}}}
$$

\section{Keterangan:}

$\mathrm{D}=$ (difference) perbedaan antara skor tes awal dengan skor tes akhir untuk setiap individu $\mathrm{N}$ = banyaknya subjek penelitian 


\section{HASIL DAN PEMBAHASAN}

Untuk kebutuhan pengolahan data hasil pengukuran kekuatan otot lengan dan hasil ketepatan melempar dan menankap boal basket pada permainan bola basket dibutuhkan tabel kerja. Berdasarkan data tersebut baik sebelum menjalani treatment maupun setelahnya seperti yang tertera pada tabel di bawah ini : Kerja Penghitungan Pengaruh Latihan bench dip(X) terhadap kemampuan passing Bola Basket (Y).

Tabel 1. Tabel Kerja

\begin{tabular}{|c|l|c|c|c|c|}
\hline \multirow{2}{*}{ No } & \multirow{2}{*}{ Nama } & \multicolumn{2}{c|}{ Kemampuan passing bola basket } & \multirow{2}{*}{ D } & \multirow{2}{*}{ D2 } \\
\cline { 3 - 5 } & & Pree-test & Post-test & & \\
\hline 1 & Abim teheran & 14 & 17 & 3 & 9 \\
\hline 2 & Adrian rahman & 14 & 18 & 4 & 16 \\
\hline 3 & Ahmad izzadin ilham & 13 & 16 & 3 & 9 \\
\hline 4 & Ardiansyah & 15 & 19 & 4 & 16 \\
\hline 5 & Atma dwi oktafian & 17 & 21 & 4 & 16 \\
\hline 6 & Gede sujana & 17 & 20 & 3 & 9 \\
\hline 7 & Gilang ramadhan & 16 & 19 & 3 & 9 \\
\hline 8 & Hafgan wira fasrudi & 15 & 19 & 4 & 16 \\
\hline 9 & Irlan zakaria & 17 & 21 & 4 & 16 \\
\hline 10 & Joni hidayat & 15 & 18 & 3 & 9 \\
\hline 11 & M.Gibran aseryazid & 14 & 18 & 4 & 16 \\
\hline 12 & Naufal muzaki & 13 & 18 & 5 & 25 \\
\hline 13 & Noufal pramudya farakhan & 15 & 19 & 4 & 16 \\
\hline 14 & Panji yudana rangkuti & 15 & 18 & 3 & 9 \\
\hline 15 & Rahman yadi & 16 & 19 & 3 & 9 \\
\hline 16 & Rahma atma & 14 & 17 & 3 & 9 \\
\hline 17 & Ripaldi & 17 & 20 & 3 & 9 \\
\hline 18 & Sunandi raja & 16 & 19 & 3 & 9 \\
\hline 19 & Yudha bakti & 16 & 20 & 4 & 16 \\
\hline 20 & Zikri kurniawan & 17 & 21 & 4 & 16 \\
\hline & & 306 & 377 & 71 & 259 \\
\hline
\end{tabular}

Memasukkan data kedalam rumus (analisa data).

$$
\begin{aligned}
& t=\frac{\sum D}{\sqrt{\frac{N \cdot \sum D^{2}-\left(\sum D\right)^{2}}{(N-1)}}} \\
& t=\frac{71}{\sqrt{\frac{20.259-5041}{(20-1)}}}
\end{aligned}
$$




$$
\begin{gathered}
t=\frac{71}{\sqrt{\frac{5180-5041}{19}}} \\
t=\frac{71}{\sqrt{\frac{139}{19}}} \\
t=\frac{71}{\sqrt{7,31}} \\
t=\frac{71}{2,7} \\
t=26,29
\end{gathered}
$$

Hasil dan pembahasan penelitian ini maka Pengaruh latihan bench dip terhadap kemampuan passing bola basket pada SMAN 1 Narmada Tahun 2020, Setelah mendapat nilai dari "t" hitung dengan df $(\mathrm{N}-1)=19$ maka nilai " $t$ " hitung menunjukkan angka 26,29 > dari pada " $t$ " tabel dengan angka 2,069 atas dasar taraf signifikansi 5\% berarti signifikan. Dilihat dari hasil perbandingan tersebut bahwa " $t$ " hitung sebesar 26,29 > "t" tabel sebesar 2,069 pada taraf signifikansi, dengan kata lain hasil akhirnya sangat signifikansi dalam dua taraf signifikansi pengujian. Dengan dasar ini, hipotesis nol (Ho) yang berbunyi "Tidak Pengaruh latihan bench dip terhadap kemampuan passing bola basket pada SMAN 1 Narmada Tahun 2020, Ditolak. Sedangkan hipotesis alternatif (Ha) yang berbunyi" Pengaruh latihan bench dip terhadap kemampuan passing bola basket pada SMAN 1 Narmada Tahun 2020, Diterima.

Penelitian tentang faktor-faktor yang dapat mempengaruhi hasil passing bola basket pada permainan bola basket sangat penting dilakukan karena kemampuan passing bola basket dapat membantu mendapatkan skor yang tinggi dan mendapat kemenangan dalam permainan. Dalam permainan bola basket, apabila kemampuan passingnya bagus maka peluang untuk menguasai jalannya permainan lebih baik.Sehingga bisa dikatakan kemenangan sudah jelas dimilki oleh tim basket yang memiliki kemampuan passing bola basket dengan tepat. Penelitian yang bertujuan“ Ingin mengetahui Pengaruh latihan bench dip terhadap kemampuan passing bola basket pada SMAN 1 Narmada Tahun 2020". Ini menunjukan bahwa ada Pengaruh latihan bench dip terhadap kemampuan passing bola basket, hal ini menjadi informasi penting bagi guru pendidikan jasmani dan Kesehatan serta pelatih dalam melekukan pemanduan bakat terhadap para pemain bola basket. Dalam pelaksanaan latihan passingbola basket kekuatan otot lengan perlu diberikan latihan bench dip secara bertahap karena telah terbukti dapat meningkatkan kemampuan passing bola dalam permainan bola basket. Pelaksanaan latihan harus menerapkan prinsip-prinsip latihan yang benar agar tujuan latihan dapat dicapai secara optimal.

Pulung Riyanto, 2019 dengan judul Perbandingan Pengaruh Latihan Bench Press dan Push Up terhadap Peningkatan Keterampilan Chest Pass. Permainan bola basket dilakukan dengan mempergunakan tiga unsur teknik yang menjadi pokok permainan, yakni : mengoper (passing), menangkap bola (catching), menggiring bola (dribbling), dan menembakan bola ke keranjang (shooting). Ketiga unsur teknik berkembang menjadi bermacam-macam teknik lanjutan yang memungkinkan permainan bola basket bervariasi. Misalnya, dalam teknik mengoper dan menangkap bola terdapat beberapa cara seperti : lemparan dada (chest pass), lemparan dari atas kepala (overhead pass), lemparan pantul (bounce pass), dan lain sebagainya. Seorang pemain bola 
basket yang sudah menguasai dan terampil dalam permainan bola basket harus memiliki kondisi fisik yang baik. Salah satu unsur kemampuan fisik yang penting dalam permainan bola basket adalah power/kekuatan. Seorang pemain bola basket mampu melakukan passing chest pass, bounce pass, over head pass dengan cepat dan tepat berarti atlet telah memiliki kekuatan otot lengan yang terlatih karena atlet tersebut sudah mempersiapkannya secara matang sebelum menghadapi pertandingan. Proses latihan berlangsung selama dua bulan, dan dilatih sesuai dengan program latihan. Berdasarkan hasil penghitungan dan analisis data yang telah diuraikan maka kesimpulan dalam penelitian ini adalah Terdapat pengaruh yang signifikan dari latihan bench press terhadap hasil chest pass dalam permainan bola basket di SMA Negeri 3 Subang.Terdapat pengaruh yang signifikan dari latihan push up terhadap hasil chest pass dalam permainan bola basket di SMA Negeri 3 Subang. Latihan bench press lebih signifikan pengaruhnya terhadap keterampilan chest pass dibandingkan dengan latihan push up. Terdapat pengaruh yang signifikan dari latihan bench press terhadap hasil chest pass dalam permainan bola basket di SMA Negeri 3 Subang.

Rian Kusuma Junaedi, 2015 Pengaruh latihan kekuatan otot lengan terhadap ketepatan melempar dan menangkap bola basket pada siswa putra kelas VIII SMPN 2 Lingsar tahun pelajaran 2014/2015. Dengan kekuatan otot lengan terhadap ketepatan melempar bola basket yang sudah menguasai dan terampil dalam permainan bola basket harus memiliki kondisi fisik yang optimal sehingga dapat melakukan ketepatan melempar dan menangkap bola basket. Salah satu unsur kemampuan fisik yang penting dalam permainan bola basket adalah kekuatan. Seorang pemain bola basket mampu melakukan passing chest pass, bounce pass, over head pass dengan cepat dan tepat berarti atlet telah memiliki kekuatan otot lengan yang terlatih karena atlet tersebut sudah mempersiapkannya secara matang sebelum menghadapi pertandingan. Hasil penelitian: $\mathrm{n}=19$ maka nilai "t" hitung menunjukkan angka 3.439> dari pada "t" tabel dengan angka 2.069 atas dasar taraf signifikansi 5\% berarti signifikan. Ada Pengaruh latihan kekuatan otot lengan terhadap ketepatan melempar dan menangkap bola basket pada siswa putra kelas VIII SMPN 2 Lingsar tahun pelajaran 2014/2015.

Witarsyah, dan Yolly Devira, dengan judul Pengaruh Latihan Beban Menggunakan Alat Terhadap Kemampuan Chest Pass, dalam masalah dalam penelitian ini adalah kurangnya kemampuan chest pass atlet bolabasket klub Batavia Padang. Tujuan dilakukan penelitian ini untuk mengetahui adakah pengaruh latihan beban menggunakan alat terhadap kemampuan chest pass atlet bolabasket klub Batavia Padang. Penelitian ini merupakan penelitian eksperimen semu. Penelitian dilaksanakan pada tanggal 4 Juli sampai 7 Agustus 2019 di lapangan basket SMA Pembangunan Padang. Populasi dalam penelitian ini sebanyak 22 orang yang terdiri dari 10 orang putra dan 12 orang putri. Sampel dalam penelitian ini adalah atlet bolabasket putra tingkat sma pembangunan Padang yang berjumlah 10 orang. Penelitian dilakukan sebanyak 16 kali pertemuan dimana dalam 1 minggu ada 4 kali latihan. Instrumen dalam penelitian ini menggunakan Wallbounce Basketball Passing Test. Teknik analisis data dalam penelitian ini menggunakan rumus uji t. Dari hasil penelitian dan pengujian hipotesis dapat ditarik kesimpulan bahwa terdapat pengaruh yang signifikan dari latihan beban menggunakan alat terhadap kemampuan chest pass atlet bolabasket klub Batavia Padang. bahwa ada pengaruh yang signifikan dari latihan menggunakan alat terhadap kemampuan chest pass atlet bolabasket klub Batavia Padang.

Hasil Penelitian ini di deskrifsikan tentang faktor-faktor yang dapat mempengaruhi hasil passing bola basket pada permainan bola basket sangat penting dilakukan karena kemampuan passing bola basket. Dengan adanya kekuatan yang baik maka dapa meningkatkan prestasi atlet. Bompa merupakan kemampuan otot dan saraf tubuh untuk mengatasi beban internal dan beban eksternal. Menurut Friedrich Pengertian kekuatan menurut Friedrich ialah kemampuan yang 
dimiliki otot untuk bekerja menahan beban secara maksimal. Syahfrizar (2007), faktor-faktor yang mempengaruhi kekuatan antara lain: ukuran otot, jenis serabut otot, jumlah motor unit kerja. System metabolisme, energi, aspek biomekanika, kinesiologi, meliputi sudut sendi. Sementara menurut (Friedrich, 1969) dalam buku Syahfrizar (2007:73), yang mempengaruhi kekuatan seperti biomekanika, faktor ukuran otot. Faktor fisiologis itu mempengaruhi seberapa besar kekuatan yang dimiliki oleh seseorang. Dari uraian di atas, dapat disimpulkan bahwa banyak faktor yang mempengaruhi kekuatan seseorang diantaranya faktor biomekanika,faktor ukuran otot, jenis kelamin, faktor usia, kesemuanya itu dapat mempengaruhi kekuatan seseorang. Dengan Latihan beban yang diberikan latihan bench dip secara bertahap. Bench dip merupakan salahsatu teknik untuk meningkatkan kekuatan otot trisep.Dalam melakukan latihan Bench dip posisi tumpuan kedua tangan harus lebih tinggi dari lantai yang dimana ketika melakukan gerakan tangan di tekuk ke belakang tubuh dengan posisi kaki lurus kedepan.Dalam hal ini, tempat untuk bertumpu bisa di bantu dengan menggunakan media seperti kursi.Hal ini dapat membuat otot trisep berkontraksi secara penuh.Otot trisep adalah otot lengan atas bagian belakang. Thomas (dalam Ramadhon :2008). Dalam latihan berbeban lebih mengacu pada latihan yang bersifat kekhususan atau spesifik. Berdasarkan Latihan bench dip ini adalah Latihan untuk otot lengan. Otot lengan adalah kumpulan dari benang-benang yang panjang yang dibuat dari sel-sel dan dikelompokkan dalam satu ikatan yang terdapat di lengan (Sunyoto, 2007: 52). Setiap ikatan secara terpisah"dibungkus" dalam suatu jaringan ikat yang menahan atau menyatukan dan melindungi otot.Otot-otot itu diatur dalam pasangan-pasangan kerja agar terjadi gerak yang dibuat oleh pasangan-pasangan otot tadi. salah satu faktor yang harus diperhatikan dalam olahraga khususnya pada permainan bola basket, karena otot lengan akan memungkinkan dalam pencapaian prestasi yang maksimal, dalam hal passing chas pass bola basket. Dalam pelaksanaan latihan passingbola basket kekuatan otot lengan perlu diberikan latihan bench dip secara bertahap karena telah terbukti dapat meningkatkan kemampuan passing bola dalam permainan bola basket. Pelaksanaan latihan harus menerapkan prinsip-prinsip latihan yang benar agar tujuan latihan dapat dicapai secara optimal.

\section{KESIMPULAN}

Berdasarkan hasil analisis data yang telah dibuktikan bahwa latihan bench dip mempunyai pengaruh positif terhadap kemampuan passingbola, maka upaya untuk meningkatkan kekuatan otot lengan perlu dilakukan oleh seorang pemain ataupun pelatih agar kemampuan untuk melakukan passingbola basket semakin baik. Oleh karena itu melalui kesempatan ini peneliti menyampaikan bebrapa saran bagi pemain dan pelatih serta peneliti yang berhubungan dengan upaya kemampuan seorang pemain bola basket, yaitu antara lain:

1) Pemain: meningkatkan kemampuan latihan passing bola basket dengan melakukan latihan kekuatan otot lengan dengan berbagai bentuk latihan fisik. Salah satunya dengan menggunakan latihan bench dip.

2) Pelatih: memberikan latihan-latihan fisik dan teknik yang betujuan untuk meningkatkan kemampuan passing bola basket pada pemain.

3) Peneliti: melakukan penelitian yang berhubungan dengan upaya peningkatan kekuatan otot lengan dengan menggunakan subyek penelitian yang berbeda.

4) Siswa, pelatih guru penjas: manfaatkan hasil penelitian ini dalam proses pembelajaran bola basket khususnya terhadap upaya peningkatan kemampuan passing bola basket. 


\section{DAFTAR PUSTAKA}

Arikunto, Suharsimi. 2009. Manajemen Penelitian. Jakarta: PT Rineka Cipta.

Arikunto, Suharsimi. 2010. Prosedur Penelitian Suatu Pendekatan Praktek. Jakarta: Rineka Cipta.

Giriwijoyo (2007). Kesehatan, kebugaran jasmani dan olahraga. Sari bahan kuliah ITB. Manusia dan olahraga.

Halim, Nur Ichsan. 2011. Tes Dan Pengukuan Kesegaran Jasmani. Makassar: Universitas Negeri Makassar.

Hasan, M. Iqbal. 2008. Pokok-Pokok Materi Statistik 2 (Statistik Inferensif). PT Bumi Aksara.

Hulfian, L. 2014. Penelitian Dikjas. Lombok Timur: Garuda Ilmu.

Riyanto, P. 2019. Perbandingan Pengaruh Latihan Bench Press dan Push Up terhadap Peningkatan Keterampilan Chest Pass. Journal Of Physical And Outdoor Education Volume 1 No. 1 April 2019

Nuril Ahmadi. (2007). Permainan Bola Basket.Surakarta, Era Intermedia

Sugiyono. 2013. Metodologi Penelitian Kuantitatif, Kualitatif, Dan R\&D. Bandung: C.V. Alfabeta.

Supranto, J. 2009. Edisi Ketujuh Statistik Teori Dan Aplikasi. Erlangga.

Suryabrata. 2014. Metodologi penelitian cetakan ke 25. Jakarta: PT Rajagrafindo Persada.

Sukandarrumidi. (2014). Metodologi penelitian, Yogyakarta: Gajah Mada University Press.

Sugiyono. 2012. Metode penelitian kuantitatif kualitatif dan R\&D. Bandung: Alfabeta.

Sukandarrumidi. 2004. Metodologi Penelitian: Petunjuk praktis untuk Peneliti Pemula. Yogyakarta: Gajah Mada University Press

Wissel. 2000. Bola basket. Jakarta: PT. Raja Girafindo Persada. 